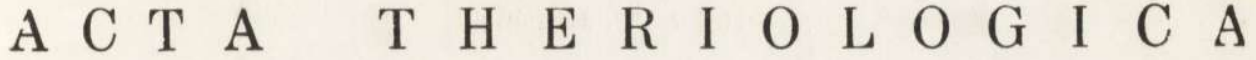

VOL. XVI, 31: $471-481$.

BIAŁOWIEŻA

December, 1971

BISONIANA XLVI

Stanisław P Y T EL \& Małgorzata KRAS I N S K A

\section{Morphology of the Stomach and Intestines in Hybrids of European Bison and Domestic Cattle}

[With 8 Tables]

Morphological observations and measurements of the stomach and intestines were based on material obtained from 21 hybrids of different generations of European bison crossbred with domestic cattle (15 $\sigma^{x} \sigma^{7}$ and 6 우 ) from 6 months to 9 years old. The phenomenon of heterosis was found to exist in hybrids of the first generation $\left(F_{1}\right)$, in relation to morphological characters and dimensions; characters of heterosis decrease in $\mathrm{B}_{1}$ generation. In adult $\mathrm{F}_{1}$ males stomach capacity is on an average $289.18 \mathrm{l}$, whereas in $\mathrm{B}_{1}$ it is only $179.03 \mathrm{l}$. The small intestine in adult $\mathrm{F}_{1}$ males is on an average $53.80 \mathrm{~m}$ in length and has a capacity of $82.41 \mathrm{l}$, whereas in $B$, the corresponding values are $43.24 \mathrm{~m}$ and $53.61 \mathrm{l}$. The large intestine in adult $F_{1}$ males is on an average $13.52 \mathrm{~m}$ long (cecum $-0.94 \mathrm{~m}$ ) and has a capacity of 53.221 , whereas in $B_{1}$ the corresponding values are $10.25 \mathrm{~m}$ and $28.03 \mathrm{l}$. The relative length of the small intestine in adult $F_{1}$ males is on an average $1: 19.49$, but in $B_{1}-1: 17.30$; these data for the large intestine are respectively $1: 4.90$ and $1: 4.10$.

\section{INTRODUCTION}

Experiments on crossbreeding European bison and domestic cattle have been carried out in the Mammals Research Institute of the Polish Academy of Sciences at Białowieża since 1958. Two breeds of domestic cattle were used for crossbreeding - the Polish red and black and white lowland cattle (D e hne 1, 1960, 1961; D e mi a s z ki ew i c z, 1961; K r asińska, 1963, 1967, 1969; Krasińsk a P u c e k, 1967). Up to the end of 1970 we obtained a total of $10 \mathrm{~F}_{1}$ hybrids and 25 of the backcross generation $\left(3 / 4\right.$ domestic cattle $\left.-B_{1}\right)$ and 8 of the $B_{2}$ generation $(7 / 8$ domestic cattle). In the earlier phases of the experiment the development of hybrids was traced by studying the results of measurements and body weight (K r a sińska, 1969). These studies were supplemented by analysis of the characters of anatomical structure. From 1968-1969 22 hybrids from different generations were chosen in order to analyse the value for use of their meat, and hide, and the structure of internal organs and of the skeleton. 
The present study is concerned with morphological analysis of the ventral part of the alimentary tract. Comparison has also been made of the structural characters of the stomach and intestines in hybrids and parental forms. A good knowledge has been obtained in this respect of one of the partners used for crossbreeding, i.e., the European Bison (P i ękoś, Pilarski \& Roskosz, 1958; Gill, 1968; P ytel, 1969), but no anatomical data for the given breeds of cattle were found in literature.

\section{MATERIAL AND METHODS}

The material consisted of the stomach and intestines of 21 hybrids (Table 1) of the following origin: 5 adult individuals from the first generation $\left(\mathrm{F}_{1}\right), 10$ adults

Table 1

Material examined.

\begin{tabular}{|c|c|c|c|c|c|c|}
\hline \multirow{2}{*}{ No. } & \multirow{2}{*}{ Name } & \multirow{2}{*}{ Generation } & \multirow{2}{*}{$\begin{array}{l}\text { Age, } \\
\text { years }\end{array}$} & \multicolumn{2}{|c|}{ Measurements of body $\mathrm{cm}$} & \multirow{2}{*}{ Weight } \\
\hline & & & & $A^{*}$ & $a^{* *}$ & \\
\hline & \multicolumn{6}{|c|}{ Males } \\
\hline 1 & Fakir & $\mathrm{F}_{1}$ & 5.0 & 275 & 210 & $841^{* * *}$ \\
\hline 2 & Farad & $\mathrm{F}_{1}$ & 6.5 & 287 & 220 & 1015 \\
\hline 3 & Filip & $\mathrm{F}_{1}$ & 8.0 & 266 & 188 & 885 \\
\hline 4 & Fest & $\mathrm{B}_{1}$ & 0.5 & 184 & 118 & 263 \\
\hline 5 & Felon & $\mathrm{B}_{1}$ & 0.5 & 183 & 130 & 286 \\
\hline 6 & Feld & $\mathrm{B}_{1}$ & 1.5 & 226 & 150 & 380 \\
\hline 7 & Fellach & $\mathrm{B}_{1}$ & 2.0 & 240 & 165 & 500 \\
\hline 8 & Festyn & $\mathrm{B}_{1}$ & 2.5 & 240 & 171 & 540 \\
\hline 9 & Fen & $\mathrm{B}_{1}$ & 3.5 & 261 & 160 & 580 \\
\hline 10 & Feg & $\mathrm{B}_{1}$ & 3.5 & 248 & 169 & 552 \\
\hline 11 & $\mathrm{Feb}$ & $\mathrm{B}_{1}$ & 3.5 & 257 & 160 & 540 \\
\hline 12 & Fey & $\mathrm{B}_{1}$ & 4.0 & 248 & 170 & 675 \\
\hline 13 & Fetysz & $\mathrm{B}_{1}$ & 4.5 & 263 & 171 & 567 \\
\hline 14 & Fez & $\mathrm{B}_{1}$ & 4.5 & 249 & 170 & 613 \\
\hline 15 & Fenix & $\mathrm{B}_{1}$ & 5.5 & 226 & 159 & $520 * * *$ \\
\hline \multicolumn{7}{|c|}{ Females } \\
\hline 1 & Filutka & $\mathrm{F}_{1}$ & 7.0 & 229 & 145 & 490 \\
\hline 2 & Fama & $\mathrm{F}_{1}$ & 9.0 & 234 & 160 & 532 \\
\hline 3 & Felly & $\mathrm{B}_{1}$ & 1.0 & 195 & 130 & 279 \\
\hline 4 & Ferma & $\mathrm{B}_{1}$ & 1.5 & 191 & 134 & 284 \\
\hline 5 & Fema & $\mathrm{B}_{1}$ & 2.5 & 222 & 145 & 330 \\
\hline 6 & Fela & $\mathrm{B}_{2}$ & 2.5 & 223 & 147 & 429 \\
\hline
\end{tabular}

* Body length (distince between the upper edge of the nosolabial plate and the tail basis).

** Oblique length of the trunc (distance between the scapulo-humeral articulation and the ischiadic tubercule).

*** Castrates.

backcrosses $\left(3 / 4\right.$ cattle blood $\left.-B_{1}\right)$. The other juvenile individuals were obtained from generation $\mathrm{B}_{1}$, and one from $\mathrm{B}_{2}$. There were 15 males in the study material (including 2 castrates) and 6 females. Body measurements were made after $\mathrm{P}$ ię k oś 
et al. (1958) and Lisk un (1949). Measurements of stomach and intestinal capacity and length of intestines were made by the method used earlier on for the European bison (P y te 1, 1969). The field conditions for analysis made some degree of simplication necessary, for instance separate measurements were made only for total volume of the compartments: rumen-reticulum and omasum-abomasum (Table 3).

\section{RESULTS}

\section{Morphological Observations}

The relatively low caudal pillar in the rumen $(6 \mathrm{~cm})$ is remarkable. The total number of omasal laminae varies from 141 to 190 (Table 2a). For comparative reasons this table does not include the six-order laminae occurring in 9 cases - folds which are sometimes only visible after removing stratified squamous epithelium, and sometimes attain a width of $0.5 \mathrm{~cm}$. The numbers of these laminae vary greatly $(3-71)$. In two cases the phenomenon was observed of branching of the free margins of the longest laminaf usually numbering from $11-12$, and the consequent

Table 2

Number of omasal laminae $(a)$ and abomasal spiral folds $(b)$ in $F_{1}$ and $B_{1}$ hybrids.

\begin{tabular}{|c|c|c|c|c|c|c|c|c|}
\hline \multirow{2}{*}{$\begin{array}{l}\text { Order of } \\
\text { laminae* }\end{array}$} & \multicolumn{4}{|c|}{$C^{*} C^{\circ}(N=15)$} & \multicolumn{4}{|c|}{$q q(\mathrm{~N}=6)$} \\
\hline & O. R. & Avg. & S. D. & C. v. & O. R. & Avg. & S. D. & C. v. \\
\hline \multicolumn{9}{|c|}{$a$} \\
\hline 1 & $10-14$ & 11.60 & \pm 1.08 & 9.31 & $10-14$ & 12.00 & \pm 1.29 & 10.75 \\
\hline 2 & $11-15$ & 12.67 & \pm 1.34 & 10.58 & $11-15$ & 13.00 & \pm 1.53 & 11.77 \\
\hline 3 & $21-30$ & 24.54 & \pm 2.43 & 9.91 & $21-29$ & 25.00 & \pm 2.38 & 9.52 \\
\hline 4 & $40-55$ & 46.67 & \pm 2.26 & 4.84 & $40-51$ & 47.17 & \pm 3.58 & 7.57 \\
\hline 5 & $49-86$ & 73.67 & \pm 9.34 & 12.66 & $76-82$ & 79.17 & \pm 1.81 & 2.29 \\
\hline Total & $141-190$ & 169.40 & \pm 14.27 & 8.42 & $159-185$ & 176.33 & \pm 8.39 & 4.76 \\
\hline$b$ & $17-25$ & 20.80 & \pm 2.01 & 9.66 & $16-20$ & 18.00 & \pm 1.28 & 7.71 \\
\hline
\end{tabular}

* Figures from 1 to 5 indicate respectively first to fifth - order laminae.

number of lower laminae is characterized by the highest variability coefficient among the shortest laminae (fifth-order) in males and of laminae second in order of length (second-order laminae) in females.

The average number of spiral folds of the abomasum (Table $2 b$ ) is 18 (females) and 20.8 (males), these figures not including the so-called secondary folds encountered in 8 of the individuals examined, in which they number from $1-2$. The largest of the folds has an average height of $9.5 \mathrm{~cm}$.

A transverse fold occurs between the folds lying nearest the smaller curvature, in the vicinity of the omaso-abomasal opening. The degree 
of its development varies, and it attains a considerable height, up to $4 \mathrm{~cm}$, in 11 hybrids. The extent of mucosa of abomasum on the surface of the fold running towards omasum, is $1-2.8 \mathrm{~cm}$.

Ansa spiralis coli in the majority of cases (17) has two centripetal and centrifugal gyri, in 3 cases (all from generation $\mathrm{B}_{1}$ ) - one and a half gyri, in one case (generation $F_{1}$ ) two and a half gyri. In this last case this is confirmed in the exceptionally long large intestine $-14.90 \mathrm{~m}$. of which the colon forms more than $13 \mathrm{~m}$.

On the final most peripherally situated centrifugal gyrus an U-shaped accessory loop was found in two males, while the gyrus itself in 9 cases

Table 3

Capacity of stomach compartments (in litres and $\%$ of capacity of whole stomach.

\begin{tabular}{|c|c|c|c|c|c|c|c|}
\hline \multirow[t]{2}{*}{ Group } & \multirow[t]{2}{*}{$\mathrm{N}$} & & \multirow{2}{*}{$\begin{array}{l}\text { Whole } \\
\text { stomach }\end{array}$} & \multicolumn{2}{|c|}{ Rumen + Reticulum } & \multicolumn{2}{|c|}{$\begin{array}{c}\text { Omasum }+ \text { Abo- } \\
\text { masum }\end{array}$} \\
\hline & & & & Abs. & $\stackrel{q}{0}$ & Abs. & : \\
\hline \multicolumn{8}{|c|}{ Males } \\
\hline $\begin{array}{l}\text { Calves } B_{1} \\
6 \text { month }\end{array}$ & 2 & $\min _{\bar{x}}$ & $\begin{array}{l}41.74 \\
62.22 \\
51.98\end{array}$ & $\begin{array}{l}31.98 \\
48.80 \\
40.39\end{array}$ & $\begin{array}{l}77 \\
78 \\
78\end{array}$ & $\begin{array}{r}9.76 \\
13.42 \\
11.59\end{array}$ & $\begin{array}{l}22 \\
23 \\
22\end{array}$ \\
\hline $\begin{array}{l}\text { Young } B_{1} \\
1.5-2.5 \text { yrs. }\end{array}$ & 3 & $\min _{\vec{x}}$ & $\begin{array}{l}166.40 \\
210.00 \\
185.88\end{array}$ & $\begin{array}{l}136.22 \\
168.75 \\
150.82\end{array}$ & $\begin{array}{l}80 \\
82 \\
81\end{array}$ & $\begin{array}{l}30.18 \\
41.25 \\
35.06\end{array}$ & $\begin{array}{l}18 \\
20 \\
19\end{array}$ \\
\hline $\begin{array}{l}\text { Adult } \mathrm{B}_{1} \\
3.5-5.5 \mathrm{yrs} \text {. }\end{array}$ & 7 & $\min _{\bar{x}}$ & $\begin{array}{l}136.47 \\
215.94 \\
179.03\end{array}$ & $\begin{array}{l}101.80 \\
170.50 \\
141.74\end{array}$ & $\begin{array}{l}75 \\
83 \\
79\end{array}$ & $\begin{array}{l}31.25 \\
51.24 \\
37.29\end{array}$ & $\begin{array}{l}17 \\
25 \\
21\end{array}$ \\
\hline $\begin{array}{l}\text { Adult } F_{1} \\
5-8 \text { yrs. }\end{array}$ & 3 & $\min _{\bar{x}}$ & $\begin{array}{l}235.34 \\
335.50 \\
289.18\end{array}$ & $\begin{array}{l}189.40 \\
280.20 \\
236.27\end{array}$ & $\begin{array}{l}80 \\
83 \\
82\end{array}$ & $\begin{array}{l}45.92 \\
57.50 \\
52.91\end{array}$ & $\begin{array}{l}17 \\
20 \\
18\end{array}$ \\
\hline \multicolumn{8}{|c|}{ Females } \\
\hline $\begin{array}{l}\text { Young } \mathrm{B}_{1}+\mathrm{B}_{2} \\
1-2.5 \mathrm{yrs} \text {. }\end{array}$ & 4 & $\min _{\overline{\mathrm{x}}}$ & $\begin{array}{r}71.98 \\
162.34 \\
117.53\end{array}$ & $\begin{array}{r}50.02 \\
133.48 \\
94.00\end{array}$ & $\begin{array}{l}70 \\
84 \\
80\end{array}$ & $\begin{array}{l}17.50 \\
28.86 \\
23.54\end{array}$ & $\begin{array}{l}16 \\
30 \\
20\end{array}$ \\
\hline $\begin{array}{l}\text { Adult } F_{1} \\
7-9 \text { yrs. }\end{array}$ & 2 & $\min _{\overline{\bar{x}}}$ & $\begin{array}{l}162.31 \\
213.50 \\
187.90\end{array}$ & $\begin{array}{l}129.91 \\
172.02 \\
150.96\end{array}$ & $\begin{array}{l}80 \\
81 \\
80\end{array}$ & $\begin{array}{l}32.40 \\
41.48 \\
36.94\end{array}$ & $\begin{array}{l}19 \\
20 \\
20\end{array}$ \\
\hline
\end{tabular}

parted for 5-10 $\mathrm{cm}$ from the whole of ansa spiralis coli. In one case ansa spiralis takes a form intermediate between a disc and a cone.

\section{Results of Measurements}

2.1. S to $\mathrm{mach}$. As can be seen from the date in table 3 the average capacity of the stomach in adult $\mathrm{B}_{1}$ males is $179 \mathrm{l}$ and is $38 \%$ lower than in adult $F_{1}$ males, the rumen and reticulum being $40 \%$ smaller, omasum and abomasum $-30 \%$. 


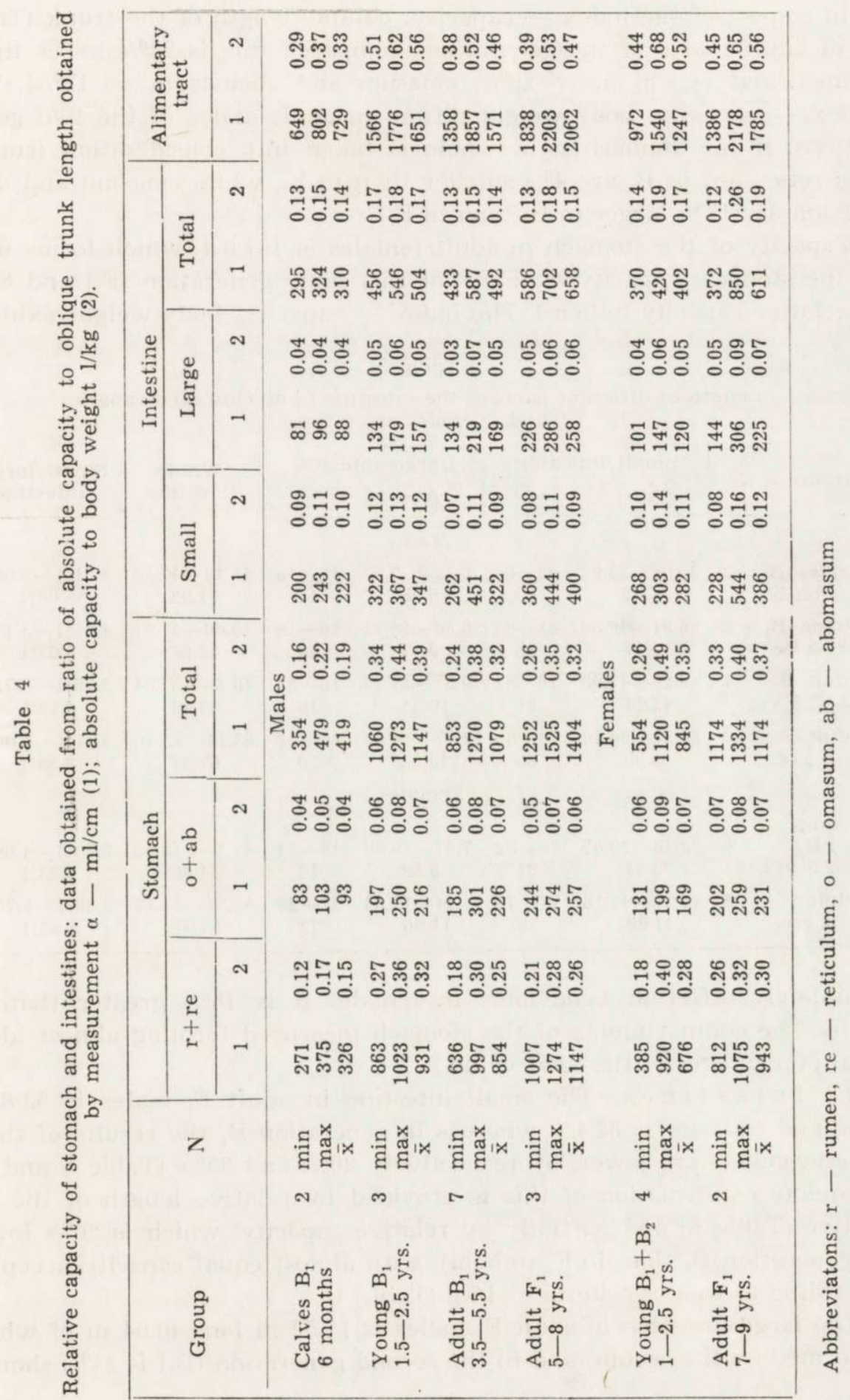


In respect of the index - capacity: oblique length of the trunk (Table 4 ) of adult males of the generations compared this is $23 \%$ lesser in $B_{1}$ (rumen and reticulum $-26 \%$, omasum and abomasum $-12 \%$ ). The index - capacity: body weight differs in adult males of the two generations, if the stomach as a whole is taken into consideration (rumen and reticulum in $B_{1}$ are $4 \%$ smaller than in $F_{1}$, while omasum and abomasum are $17 \%$ larger in $B_{1}$ than in $F_{1}$ ).

Capacity of the stomach in adult females is $187.9 \mathrm{l}$, which forms $65 \%$ of the stomach capacity of males of this same generation $\left(\mathrm{F}_{1}\right)$ and $84 \%$ of relative capacity $(\mathrm{ml} / \mathrm{cm})$. The index - capacity: body weight exhibits

Table 5

Length of different parts of the intestine in $\mathrm{m}$. Observed ranges and averages are given.

\begin{tabular}{|c|c|c|c|c|c|c|c|}
\hline \multirow{2}{*}{ Group } & \multirow{2}{*}{$\mathrm{N}$} & \multicolumn{2}{|c|}{ Small intestine } & \multicolumn{2}{|c|}{ Large intestine } & \multirow{2}{*}{$\begin{array}{l}\text { Whole } \\
\text { intestine }\end{array}$} & \multirow{2}{*}{$\begin{array}{c}\text { Small/large } \\
\text { intestine }\end{array}$} \\
\hline & & Abs. & $q$ & Abs. & $\%$ & & \\
\hline \multicolumn{8}{|c|}{ Males } \\
\hline $\begin{array}{l}\text { Calves } B_{1} \\
6 \text { months }\end{array}$ & 2 & $\begin{array}{c}33.96-35.93 \\
34.94\end{array}$ & $\begin{array}{c}82-85 \\
83\end{array}$ & $6.42-7.53$ & $\underset{17}{15-18}$ & $\begin{array}{c}41.49-42.35 \\
41.92\end{array}$ & $\begin{array}{c}4.51: 1-5.60: 1 \\
5.00: 1\end{array}$ \\
\hline $\begin{array}{l}\text { Young } \mathrm{B}_{1} \\
1.5-2.5 \text { yrs. }\end{array}$ & 3 & $\begin{array}{c}36.91-46.89 \\
42.47\end{array}$ & $81-84$ & $\begin{array}{c}8.50-10.32 \\
9.17\end{array}$ & $\frac{16-19}{18}$ & $\begin{array}{c}45.60-57.21 \\
51.64\end{array}$ & $\begin{array}{c}4.25: 1-5.13: 1 \\
4.63: 1\end{array}$ \\
\hline $\begin{array}{l}\text { Adult } \mathrm{B}_{1} \\
3.5-5.5 \text { yrs. }\end{array}$ & 7 & $\begin{array}{l}40.28-45.98 \\
\quad 43.24\end{array}$ & $\frac{79-82}{81}$ & $\begin{array}{c}9.52-11.38 \\
10.25\end{array}$ & $\frac{16-21}{19}$ & $\begin{array}{c}49.80-55.84 \\
53.49\end{array}$ & $\begin{array}{c}3.75: 1-4.73: 1 \\
4.22: 1\end{array}$ \\
\hline $\begin{array}{l}\text { Adult } \mathrm{F}_{1} \\
5-8 \mathrm{yrs} \text {. }\end{array}$ & 3 & $\begin{array}{c}50.33-60.40 \\
53.80\end{array}$ & $\begin{array}{c}79-80 \\
80\end{array}$ & $\begin{array}{c}12.47-14.90 \\
13.52\end{array}$ & $\frac{20-21}{20}$ & $\begin{array}{c}63.14-75.30 \\
67.32\end{array}$ & $\begin{array}{c}3.81: 1-4.06: 1 \\
3.98: 1\end{array}$ \\
\hline \multicolumn{8}{|c|}{ Females } \\
\hline $\begin{array}{l}\text { Young } \\
\mathrm{B}_{1}+\mathrm{B}_{2} \\
1-2.5 \text { yrs. }\end{array}$ & 4 & $\begin{array}{c}33.78-39.07 \\
36.31\end{array}$ & $\underset{81}{79-82}$ & $\begin{array}{c}7.37-9.88 \\
8.59\end{array}$ & $\frac{18-21}{19}$ & $\begin{array}{c}41.15-48.95 \\
44.90\end{array}$ & $\begin{array}{c}3.83: 1-4.69: 1 \\
4.23: 1\end{array}$ \\
\hline $\begin{array}{l}\text { Adult } \mathrm{F}_{1} \\
7-9 \text { yrs. }\end{array}$ & 2 & $\begin{array}{c}41.79-42.18 \\
41.98\end{array}$ & $\underset{78}{78-79}$ & $\begin{array}{c}11.24-12.68 \\
11.96\end{array}$ & $\begin{array}{c}21-23 \\
22\end{array}$ & $\begin{array}{c}53.24-54.47 \\
53.94\end{array}$ & $\begin{array}{c}3.30: 1-3.75: 1 \\
3.51: 1\end{array}$ \\
\hline
\end{tabular}

completely different behaviour: in females it is $16 \%$ greater than in males, the compartments of the stomach measured forming almost identical percentages of the total value.

2.2. Intestines. The small intestine in adult $\mathrm{F}_{1}$ males is $53.8 \mathrm{~m}$ long and capacity is $82.4 \mathrm{l}$, whereas in generation $\mathrm{B}_{1}$ the results of these measurements are lower, by respectively $20 \%$ and $35 \%$ (Table 5 and 7 ). Complete confirmation of this is provided by relative length of the intestine (Table 6 ) and partially by relative capacity, which is $20 \%$ lower in generation $B_{1}$ than in $F_{1}(\mathrm{ml} / \mathrm{cm})$, with almost equal capacity accepted according to weight criteria - $1 / \mathrm{kg}$ (Table 4 ).

The large intestine in adult $\mathrm{F}_{1}$ males is $13.52 \mathrm{~m}$ long $(0.94 \mathrm{~m}$ of which is formed by the cecum) and in the second generation $\left(B_{1}\right)$ is $24 \%$ shorter 
Table 6

Ratio of body length obtained from measurement $A$ and oblique length of trunk (measurement $a$ ) to intestinal length.

\begin{tabular}{|c|c|c|c|c|c|c|c|c|}
\hline \multirow[b]{2}{*}{ Group } & \multirow{2}{*}{\multicolumn{2}{|c|}{$\mathrm{N}$}} & \multicolumn{3}{|c|}{$A$} & \multicolumn{3}{|c|}{$a$} \\
\hline & & & $\begin{array}{c}\text { Small } \\
\text { intestine }\end{array}$ & $\begin{array}{c}\text { Large } \\
\text { intestine }\end{array}$ & $\begin{array}{l}\text { Whole } \\
\text { intes- } \\
\text { tine }\end{array}$ & $\begin{array}{c}\text { Small } \\
\text { intestine }\end{array}$ & $\begin{array}{c}\text { Large } \\
\text { intes- } \\
\text { tine }\end{array}$ & $\begin{array}{l}\text { Whole } \\
\text { intestine }\end{array}$ \\
\hline \multicolumn{9}{|c|}{ Males } \\
\hline $\begin{array}{l}\text { Calves } B_{1} \\
6 \text { months }\end{array}$ & 2 & $\min _{\overline{\mathrm{x}}}^{\max }$ & $\begin{array}{l}1: 18.46 \\
1: 19.63 \\
1: 18.99\end{array}$ & $\begin{array}{l}1: 3.51 \\
1: 4.09 \\
1: 3.79\end{array}$ & $\begin{array}{l}1: 22.55 \\
1: 23.14 \\
1: 22.78\end{array}$ & $\begin{array}{l}1: 27.64 \\
1: 28.78 \\
1: 28.18\end{array}$ & $\begin{array}{l}1: 4.94 \\
1: 6.38 \\
1: 5.63\end{array}$ & $\begin{array}{l}1: 32.58 \\
1: 35.16 \\
1: 33.81\end{array}$ \\
\hline $\begin{array}{l}\text { Young } \mathrm{B}_{1} \\
1.5-2.5 \text { yrs. }\end{array}$ & 3 & $\min _{\overline{\mathrm{x}}}^{\max }$ & $\begin{array}{l}1: 16.33 \\
1: 19.54 \\
1: 18.07\end{array}$ & $\begin{array}{l}1: 3.54 \\
1: 4.30 \\
1: 3.90\end{array}$ & $\begin{array}{l}1: 20.18 \\
1: 23.84 \\
1: 21.97\end{array}$ & $\begin{array}{l}1: 24.61 \\
1: 28.42 \\
1: 26.22\end{array}$ & $\begin{array}{l}1: 4.97 \\
1: 6.25 \\
1: 5.66\end{array}$ & $\begin{array}{l}1: 30.40 \\
1: 34.67 \\
1: 31.88\end{array}$ \\
\hline $\begin{array}{l}\text { Adult } \mathrm{B}_{1} \\
3.5-5.5 \text { yrs. }\end{array}$ & 7 & $\min _{\overline{\mathrm{x}}}^{\min }$ & $\begin{array}{l}1: 16.18 \\
1: 18.71 \\
1: 17.30\end{array}$ & $\begin{array}{l}1: 3.82 \\
1: 5.04 \\
1: 4.10\end{array}$ & $\begin{array}{l}1: 20.00 \\
1: 23.75 \\
1: 21.40\end{array}$ & $\begin{array}{l}1: 23.69 \\
1: 28.09 \\
1: 26.05\end{array}$ & $\begin{array}{l}1: 5.60 \\
1: 7.16 \\
1: 6.17\end{array}$ & $\begin{array}{l}1: 29.29 \\
1: 34.90 \\
1: 32.22\end{array}$ \\
\hline $\begin{array}{l}\text { Adult } \mathrm{F}_{1} \\
5-8 \text { yrs. }\end{array}$ & 3 & $\min _{\overline{\mathrm{x}}}$ & $\begin{array}{l}1: 17.54 \\
1: 21.96 \\
1: 19.49\end{array}$ & $\begin{array}{l}1: 4.60 \\
1: 5.42 \\
1: 4.90\end{array}$ & $\begin{array}{c}1: 22.14 \\
1: 27.38 \\
1: 24.39\end{array}$ & $\begin{array}{c}1: 22.88 \\
1: 26.95 \\
1: 26.12\end{array}$ & $\begin{array}{l}1: 6.00 \\
1: 7.10 \\
1: 6.56\end{array}$ & $\begin{array}{c}1: 28.88 \\
1: 35.86 \\
1: 32.68\end{array}$ \\
\hline \multicolumn{9}{|c|}{ Females } \\
\hline $\begin{array}{l}\text { Young } B_{1}+B_{2} \\
1-2.5 \text { yrs }\end{array}$ & 4 & $\min _{\frac{\max }{\bar{x}}}$ & $\begin{array}{l}1: 15.74 \\
1: 19.52 \\
1: 17.46\end{array}$ & $\begin{array}{l}1: 3.78 \\
1: 4.45 \\
1: 4.13\end{array}$ & $\begin{array}{l}1: 19.85 \\
1: 23.68 \\
1: 21.59\end{array}$ & $\begin{array}{l}1: 23.88 \\
1: 27.82 \\
1: 26.12\end{array}$ & $\begin{array}{l}1: 5.67 \\
1: 6.81 \\
1: 6.18\end{array}$ & $\begin{array}{l}1: 30.11 \\
1: 33.76 \\
1: 32.30\end{array}$ \\
\hline $\begin{array}{l}\text { Adult } F_{1} \\
7-9 \text { yrs. }\end{array}$ & 2 & $\min _{\overline{\mathrm{x}}}^{\max }$ & $\begin{array}{l}1: 17.86 \\
1: 18.42 \\
1: 18.09\end{array}$ & $\begin{array}{l}1: 4.91 \\
1: 5.42 \\
1: 5.16\end{array}$ & $\begin{array}{l}1: 23.28 \\
1: 23.33 \\
1: 23.25\end{array}$ & $\begin{array}{l}1: 26.12 \\
1: 26.36 \\
1: 26.24\end{array}$ & $\begin{array}{l}1: 7.03 \\
1: 7.92 \\
1: 7.48\end{array}$ & $\begin{array}{l}1: 33.39 \\
1: 34.04 \\
1: 33.71\end{array}$ \\
\hline
\end{tabular}

Table 7

Capacity of different parts of intestines (1). Observed ranges and averages are given.

\begin{tabular}{|c|c|c|c|c|c|c|c|}
\hline \multirow{2}{*}{ Group } & \multirow{2}{*}{$\mathrm{N}$} & \multicolumn{2}{|c|}{ Small intestine } & \multicolumn{2}{|c|}{ Large intestine } & \multirow{2}{*}{$\begin{array}{l}\text { Whole } \\
\text { intestine }\end{array}$} & \multirow{2}{*}{$\begin{array}{l}\text { Small/large } \\
\text { intestine }\end{array}$} \\
\hline & & Abs. & $\%$ & Abs. & $\stackrel{q}{\%}$ & & \\
\hline \multicolumn{8}{|c|}{ Males } \\
\hline $\begin{array}{l}\text { Calves } B_{1} \\
6 \text { months }\end{array}$ & 2 & $\begin{array}{c}23.59-31.56 \\
27.58\end{array}$ & $68-75$ & $\begin{array}{c}10.51-11.27 \\
10.89\end{array}$ & $\begin{array}{c}25-32 \\
28\end{array}$ & $\begin{array}{c}34.86-42.07 \\
38.46\end{array}$ & $\begin{array}{c}2.09: 1-3.00: 1 \\
2.53: 1\end{array}$ \\
\hline $\begin{array}{l}\text { Young } \mathrm{B}_{1} \\
1.5-2.5 \text { yrs. }\end{array}$ & 3 & $\begin{array}{c}48.30-62.77 \\
56.28\end{array}$ & $67-71$ & $\begin{array}{c}20.18-30.59 \\
25.36\end{array}$ & $\begin{array}{c}29-33 \\
31\end{array}$ & $\begin{array}{c}68.48-93.36 \\
81.64\end{array}$ & $\begin{array}{c}2.05: 1-2.39: 1 \\
2.22: 1\end{array}$ \\
\hline $\begin{array}{l}\text { Adult } \mathrm{B}_{1} \\
3.5-5.5 \text { yrs. }\end{array}$ & 7 & $\begin{array}{c}44.82-76.69 \\
53.61\end{array}$ & $\begin{array}{c}54-77 \\
65\end{array}$ & $\begin{array}{c}21.25-37.46 \\
28.03\end{array}$ & $\begin{array}{c}23-46 \\
35\end{array}$ & $\begin{array}{c}71.82-99.80 \\
81.64\end{array}$ & $\begin{array}{c}1.20: 1-3.32: 1 \\
1.91: 1\end{array}$ \\
\hline $\begin{array}{l}\text { Adult } \mathrm{F}_{1} \\
5-8 \mathrm{yrs}\end{array}$ & 3 & $\begin{array}{c}86.35-93.20 \\
82.41\end{array}$ & $58-63$ & $\begin{array}{c}42.56-62.91 \\
53.22\end{array}$ & $\begin{array}{c}37-421 \\
39\end{array}$ & $\begin{array}{c}10.23-149.26 \\
135.63\end{array}$ & $\begin{array}{c}1.37: 1-1.72: 1 \\
1.55: 1\end{array}$ \\
\hline \multicolumn{8}{|c|}{ Females } \\
\hline $\begin{array}{l}\text { Young } B_{1}+B_{2} \\
1-2.5 \text { yrs. }\end{array}$ & 4 & $\begin{array}{c}35.97-41.78 \\
39.20\end{array}$ & $65-73$ & $\begin{array}{c}13.59-21.35 \\
16.63\end{array}$ & $\begin{array}{c}27-35 \\
30\end{array}$ & $\begin{array}{c}54.39-60.97 \\
55.82\end{array}$ & $\begin{array}{c}1.86: 1-2.65: 1 \\
2.36: 1\end{array}$ \\
\hline $\begin{array}{l}\text { Adult } F_{1} \\
7-9 \text { yrs. }\end{array}$ & 2 & $\begin{array}{c}36.49-87.02 \\
61.76\end{array}$ & $\begin{array}{c}61-64 \\
63\end{array}$ & $\begin{array}{c}23.04-48.92 \\
35.98\end{array}$ & $\begin{array}{c}36-39 \\
38\end{array}$ & $\begin{array}{c}59.53-135.94 \\
97.74\end{array}$ & $\begin{array}{c}1.58: 1-1.78: 1 \\
1.72: 1\end{array}$ \\
\hline
\end{tabular}

Acta theriol. 31 
(Table 5). The relative length of this intestine also confirms this (Table 6 ). In respect of capacity, however, this is $47 \%$ less in the second generation than in the first - absolute measurement and $44 \%$ and $17 \%$ relative measurements (Table 7 and 4).

When adult males are compared with females of the first generation $\left(F_{1}\right)$ it will be seen that the latter have a shorter small intestine $(22 \%$ shorter) and large intestine ( $12 \%$ shorter), as far as absolute measurements are concerned (Table 5). In respect of absolute capacity this is $25 \%$ less in females than males (small intestine) and $32 \%$ (large intestine) - Table 7, whereas all indices of relative capacity of the small and large intestine (Table 4) and length of large intestine (Table 6) are greater in females than in males of the same age group and the same generation.

\section{DISCUSSION}

The omasum in hybrids differs from that in European bison, not only as the result of six-order laminae occurring in some cases, but primarily because of the greater number of laminae in the various orders. The

Table 8

Comparison of stomach and intestinal capacity and intestinal length in adult bisons, hybrids and domestic cattle (European bison $=100 \%$ ).

\begin{tabular}{|c|c|c|c|c|c|c|c|c|c|}
\hline \multirow{3}{*}{ Species or generation } & \multirow{2}{*}{\multicolumn{2}{|c|}{$\begin{array}{l}\text { Stomach } \\
\text { Capacity }\end{array}$}} & \multicolumn{3}{|c|}{ Small intestine } & \multicolumn{3}{|c|}{ Large intestine } & \multirow{3}{*}{ Ref. } \\
\hline & & & \multirow{2}{*}{$\left|\frac{\text { Length }}{\mathrm{m}}\right|$} & \multicolumn{2}{|c|}{ Capacity } & \multirow{2}{*}{$\frac{\text { Length }}{\mathrm{m}}$} & \multicolumn{2}{|c|}{ Capacity } & \\
\hline & 11 & $\mathrm{ml} / \mathrm{cm}$ & & 1 & $\mathrm{ml} / \mathrm{cm}$ & & $1 \mathrm{n}$ & $\mathrm{ml} / \mathrm{cm}$ & \\
\hline European bisons & 100 & 100 & 100 & 100 & 100 & 100 & 100 & 100 & (12) \\
\hline $\begin{array}{c}\text { Hybrids } F_{1} \sigma^{x} \sigma^{x}+q \text { o } \\
\sigma^{x} \sigma^{x}\end{array}$ & $\begin{array}{l}191 \\
217\end{array}$ & $\begin{array}{l}172 \\
187\end{array}$ & $\begin{array}{l}120 \\
131\end{array}$ & $\begin{array}{l}132 \\
145\end{array}$ & $\begin{array}{l}121 \\
125\end{array}$ & $\begin{array}{l}106 \\
109\end{array}$ & $\begin{array}{l}122 \\
141\end{array}$ & $\begin{array}{l}112 \\
122\end{array}$ & \\
\hline 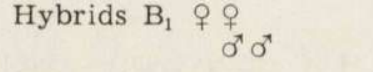 & $\begin{array}{l}143 \\
133\end{array}$ & $\begin{array}{l}166 \\
143\end{array}$ & $\begin{array}{l}102 \\
105\end{array}$ & $\begin{array}{r}114 \\
94\end{array}$ & $\begin{array}{l}113 \\
100\end{array}$ & $\begin{array}{r}100 \\
83\end{array}$ & $\begin{array}{l}91 \\
75\end{array}$ & $\begin{array}{l}92 \\
80\end{array}$ & \\
\hline Domestic cattle & $155^{*}$ & - & 100 & 111 & - & 81 & 72 & - & (1) \\
\hline
\end{tabular}

* Acc. to Frank (from S chmaltz, 1894).

transverse fold at the omasoabomasal opening, which has been described in the European bison (P y te l, 1969), occurred in half of all cases in hybrids. The number of spiral folds of the abomasum in hybrids is far greater than in cattle, and is only slightly higher than in the European bison (Py te l, 1969). The number of gyri in ansa spiralis coli in hybrids allocates them to an intermediate position between the European bison and domestic cattle (S mith \& M eadow s, 1956). 
Stomach capacity in adult $\mathrm{F}_{1}$ hybrids is almost twice greater than that of European bison (Table 8); it also exceeds data for domestic cattle, approaching that in the group of old bullocks with trunk length of 170 $205 \mathrm{~cm}(\mathrm{~S} \mathrm{chmaltz}, 1894)$. In the second generation of hybrids $\left(\mathrm{B}_{1}\right)$ stomach capacity is smaller than in cattle. Stomach capacity per $100 \mathrm{~kg}$ of body weight is about $6-81$ greater in hybrids than in European bison (W r ó blew ski, 1927; Gill, 1968; P y tel, 1969).

The small intestine in $F_{1}$ hybrids considerably exceeds data for cattle and European bison in respect of males, while differences are smaller in respect of females (Table 8). The relative length of the small intestine confirms the above conclusion. Adult males of the second generation $\left(B_{1}\right)$ have a shorter and less capacious small intestine than in the first generation, but even so it is longer than in $F_{1}$ females, and than also in European bison and cattle. The capacity of the small intestine in $\mathrm{B}_{1}$ hybrids decreases below the values characteristic of cattle.

The large intestine in adult $F_{1}$ females occupies an intermediate position between European bison and cattle in respect of capacity, but is greater (males) or equal (females) in respect of length to European bison and greatly exceeds that of cattle (Table 8 ). The relative length of the large intestine in $F_{1}$ hybrids is greater than in European bison and cattle in respect of the ratio to body length (measurement $A$ ) for males and females; it is only in relation to the oblique length of the trunk (measurement $a$ ) in female $\mathrm{F}_{1}$ hybrids that the large intestine is longer than in European bison. The large intestine in second generation males $\left(\mathrm{B}_{1}\right)$ is considerably reduced but even so is longer and more capacious than in domestic cattle.

The ratio of the small intestine to the large in $\mathrm{F}_{1}$ hybrids was on an average $3.80: 1$ (length) and $1.60: 1$ (capacity), occupying a position nearer the European bison - correspondingly $3.38: 1$ and $1.50: 1$ (P yte 1,1969$)$ than domestic cattle - correspondingly $4.60: 1$ and $4.24: 1$ (S c h m a lt z, 1894).

The phenomenon of heterosis characteristic of inter-genera hybrids has already been observed previously in the first generation of Biało-

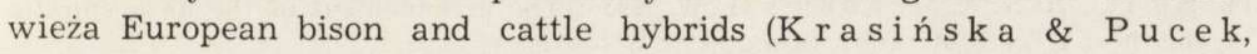
1967; Krasińska, 1969). One of the characters of this heterosis was intensive intrauterine development, manifested in considerable body weight at birth and rapid rate of development during the first year of life. Other characters in which heterosis of hybrids was revealed is their resistance to disease, great strength and capacity to withstand unfavourable climatic conditions. It should therefore be expected that the phenomenon of heterosis would be reflected in the internal structure of hybrids, and this is in fact the case. All results obtained from measure- 
ments of stomach and intestinal capacity and of measurements of intestinal length in hybrids in generation $\mathrm{F}_{1}$ exceed data for the parental forms. An exception to this is formed by some data for the large intestine, which are smaller in female hybrids than in female European bison, but this may be due to the small numbers in the groups compared.

Some of the morphological structures observed also point to the existence of the phenomenon of heterosis in the hybrids examined.

\section{REFERENCES}

1. Arutjunjan P. T., 1953: Dannye o dline, vmestimosti $\mathrm{i}$ vesovyh otnošenial kišečnika bujvola i domašnego byka. Tr. Erev. Zoovet. Inst., 15: 143-157.

2. Dehnel A., 1960: Beobachtungen über das Zusammenleben von Wisent und Hausrind. Acta theriol., 3, 14: 314-317.

3. Dehnel A., 1961: Die ersten Hybriden zwischen Bos taurus dom. L. o und Bison bonasus (L.) o. Acta theriol., 5, 3: 45-50.

4. Demiaszkiewicz W., 1961: Die Geburt eines Hybriden von Bison bonasus (L.) ơ und Bos taurus dom. L. ㅇ. . Acta theriol., 5, 4: 51-56.

5. Gill J., 1968: The capacity and weight of walls and digesta of the alimentary tract in European bison. Acta theriol., 13, 31: 499-509.

6. Kra s ińsk a M., 1963: Weitere Untersuchungen über Kreuzungen des Wisents, Bison bonasus ( $\mathrm{L}$ in n a u s, 1758) mit Hausrind, Bos taurus dom. Lin na e us, 1758. Acta theriol., 7, 14: $301-310$.

7. Kr a sińska M., 1967: Crosses of wisent and domestic cattle, V. Acta theriol., 12, 5: $67-79$

8. Kras in ska M., 1969: The postnatal development of the European bison and domestic cattle. Acta theriol., 14, 7: 69-117.

9. Krasińska M. \& Pucek Z., 1967: The state of studies on hybridisation of European bison and domestic cattle. Acta theriol., 12, 27: 385-389.

10. Lisk un E. F., 1949: Eksterer selskohozjajstvennyh životnyh. 1-311. Gos. Izd. Sielskohoz. Lit. Moskva.

11. Piękoś M., Pilarski W. \& Roskosz T., 1958: Obserwacje nad długością jelita u żubra (Bison bonasus). Folia morphol., 9: 69-79.

12. Pytel S., 1969: Morphology of digestive tract of the European bison. Acta theriol., 14, 27: 349-402.

13. S chmaltz R., 1894: Messungen von Magen und Darm des Rindes. Berl. Tierärztl. Wochschr., 52: 615-618.

14. S mith R. N. \& M e a d ow s G. W., 1956: The arrangement of the ansa spiralis of the ox colon. J. Anat. (Lond.), 90: 523-526.

15. Wróblewski K., 1927: Żubr Puszczy Białowieskiej. Wyd. Polskie: 1-232.

Accepted, July 31, 1971

Warsaw Agricultural University, Department of Animal Anatomy, Warszawa, Grochowska 272. Białowieża, Poland. 
Stanisław PYTEL i Małgorzata KRASIŃSKA

\section{MORFOLOGIA ŻOEĄDKA I JELIT MIESZAŃCOW ŻUBRA \\ I BYDEA DOMOWEGO}

\section{Streszczenie}

Obserwacje morfologiczne oraz pomiary żołądka i jelit oparto na materiale pochodzącym od 21 sztuk różnych mieszańców żubra $\mathrm{z}$ bydłem domowym $\left(15 \sigma^{\star} \sigma^{\star}\right.$ i 6 우) w wieku od 6 miesięcy do 9 lat (Tabela 1).

$\mathrm{U}$ badanych mieszańców $\mathrm{w}$ pierwszym pokoleniu $\left(\mathrm{F}_{1}\right)$ stwierdzono istnienie wybujałości cech morfologicznych i pomiarów przewodu pokarmowego. W drugim pokoleniu $\left(B_{1}\right)$ cechy heterozji zmniejszają się. U dorosłych samców $F_{1}$ pojemność żołądka wynosi średnio 289,18 l, podczas gdy u $B_{1}$ już tylko 179,03 l (Tabela 3). Długość jelita cienkiego osiąga średnio $53,80 \mathrm{~m}\left(\mathrm{~F}_{1}\right)$ i $43,24 \mathrm{~m}\left(\mathrm{~B}_{1}\right)$, natomiast jelita grubego - odpowiednio: 13,52 m i 10,25 m (Tabela 5). Względna długość jelita cienkiego samców $\mathrm{F}_{1}$ wynosi średnio $1: 19,49$, zaś u $\mathrm{B}_{1}-1: 17,30$; dane te dla jelita grubego wynoszą odpowiednio: $1: 4,90$ oraz 1:4,10 (Tabela 6). Pojemność jelita cienkiego osiąga średnio 82,41 l $\left(\mathrm{F}_{1}\right)$ i 53,61 l $\left(\mathrm{B}_{1}\right)$, natomiast jelita grubego - odpowiednio: 53,221 i 28,031 (Tabela 7 ). 